\title{
Measuring risk and returns in the customer portfolio
}

Received (in revised form): 8th October, 2001

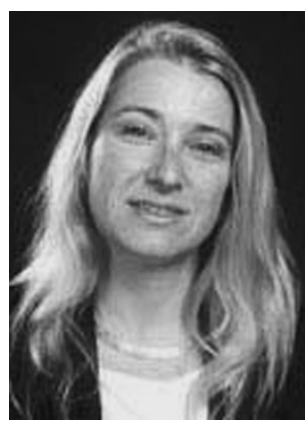

\section{Lynette Ryals}

is a lecturer in marketing at Cranfield School of Management and Director of the Executive MBA Programme. Her research interests are in CRM and how to value customer relationships. She previously worked in the City and is a Fellow of UKSIP, the society for investment professionals. She has been a guest lecturer for CIMA in Sri Lanka and for the Institute of Management in Nicosia, Cyprus.

Abstract Everybody in marketing is talking about customer relationship management (CRM), building on the relationship marketing idea that lifetime relationships with customers are more effective and profitable. But how is CRM - the management of the customer relationship over its lifetime - to be implemented? One approach is to view the customer base as an investment portfolio in which some customers will repay additional investment. The paper uses the portfolio management model of risk and return to explore the measurement of returns and of the risk of the customer. A method for assessing customer risk is described and managerial implications are outlined.

\section{INTRODUCTION}

The emergence of relationship marketing with its emphasis on customer retention ${ }^{1,2}$ and the growing body of research on the relationship between customer retention and increased profitability ${ }^{3,4}$ suggests that customer relationships are one of a business's most important assets. ${ }^{5,6}$

Various writers on marketing have emphasised that the relationship with the customer is a fundamental driver of business success ${ }^{7,8,9}$ and that customer relationship management has an important role to play in creating shareholder value. ${ }^{10,11}$

Although customers are not assets in the conventional sense of being owned by the business, the notion of customers as assets suggests that a customer base can be viewed as a portfolio in which a company invests time and resources. In business-to-business markets, this customer portfolio usually consists of a relatively few key accounts. In business-to-consumer markets, by contrast, the customer portfolio may consist of thousands or millions of individual customers. In this case, the customer portfolio may more conveniently be viewed as consisting of a number of segments which differ from one another not only by sociodemographic and attitudinal characteristics and customer needs, but also by profitability and risk and, hence, value creation. This paper explores the managerial implications of applying portfolio management theory to a portfolio of customers or customer segments. This will in turn highlight an important issue in marketing, the lack of measurement and metrics available to marketers. 


\section{RISK AND RETURN IN THE CUSTOMER PORTFOLIO}

A widely used approach to portfolio management is the capital asset pricing model (CAPM) which was developed from work in the 1960s and 1970s by Sharpe, Lintner and Black to look at risk and returns on common stocks. ${ }^{12}$ When evaluating shares, risk and return are understood to be positively correlated. High-risk (high-volatility) investments are associated with higher returns, which rational investors require to compensate them for taking on higher risk. CAPM has long been associated with the estimation of risk. ${ }^{13,14}$

There are extensive debates in the accounting literature about CAPM and its shortcomings. The debates are around two issues: how to apply it in practice; and its power to explain actual portfolio performance. According to CAPM, the return that an investor would expect from an investment would be the risk-free rate obtainable from a 'safe' investment (such as a government bond, called a 'gilt') plus a risk premium consisting of the market risk premium (measured as the excess of equity market over gilt market returns) multiplied by the specific risk of that individual investment. For example, if an investor can get a 5 per cent return by investing in a 20-year gilt and an extra 10 per cent by investing in a stock market index fund, the investor will require a 20 per cent return to invest in a company which is 50 per cent more risky than the market average ( 5 per cent $+(10$ per cent $\times 1.5)$ ).

\section{Does portfolio theory work in practice?}

There are some practical problems with portfolio theory of which managers need to be aware. One problem is how to identify the risk-free rate $^{15}$ and the appropriate risk premium.

A second problem with CAPM is that it does not always seem to hold good.

Studies have shown empirical support for CAPM in some periods and not in others. ${ }^{16}$ Grinold, for example, finds that company size and 'value' (book to price ratio) can explain expected returns better than relative risk measures, although he acknowledges that the explanatory power of a factor can change over time, ${ }^{17}$ as can the riskiness of a potential investment. ${ }^{18}$

More interesting from a managerial perspective is the idea that the relationship between risk and return might not in fact be linear. Leusner, Akhavein and Swamy ${ }^{19}$ challenge CAPM's assumption of a straight-line relationship between risk and return, arguing that in fact the true relationship is a curve and that assets do not all have the same relationship to risk. Applied to the portfolio of investments that a company makes, this might mean that some investments in certain customers or projects would have an exceptionally high payoff, despite being relatively low risk. Such investments would be powerfully value-creating, if they could be identified and acted on.

Despite its drawbacks, CAPM remains a widely used model in the evaluation of share portfolios because of its simplicity and conceptual appeal. The idea that returns must compensate for risk is also applied to the investments that companies themselves make with the funds that they borrow from the financial markets, and forms the basis of shareholder value. Proponents of shareholder value argue that companies are in business to make investments that will more than compensate for the risk of that investment. In other words, shareholder value is created only if the return on capital exceeds the cost of capital. $^{20}$ 


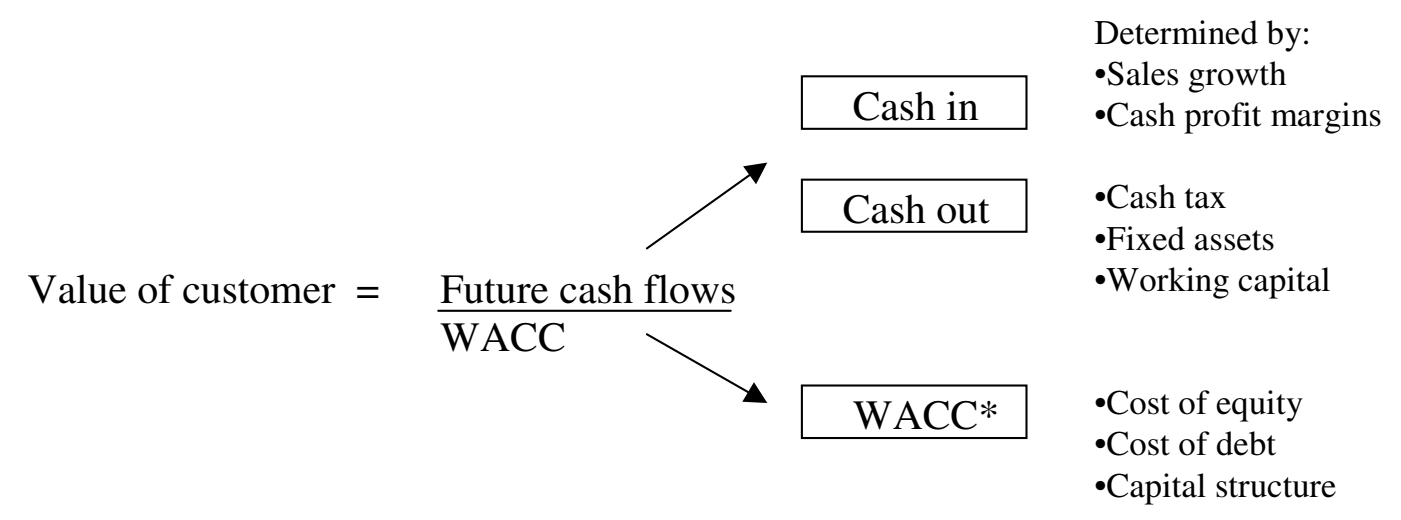

Figure 1: Seven value drivers of Free Cash Flow Source: Adapted from Black, Wright and Bachman, 1998

*Weighted Average Cost of Capital (see explanation below)

\section{CUSTOMER PROFITABILITY MEASUREMENT CAN MISLEAD}

The concept of shareholder value explains why traditional measures of customer (or segment) profitability are inadequate. Measuring customer profitability, whether using historic or future data, does not give an accurate indicator of the economic value of a customer to the organisation because the underlying measure itself, profit, does not take into account the full cost of capital. ${ }^{21}$ Indeed, certain ways of increasing revenue destroy value ${ }^{22,23}$ despite showing an accounting profit.

Similarly, it is possible that an apparently profitable customer (or segment) might not in fact create any shareholder value for a firm.

A few commentators have suggested that the principles of shareholder value should be applied to the measurement of customer profitability. ${ }^{24,25}$ Share prices are determined not just by current company profitability, but by future profits adjusted for the cost of capital, which is affected by risk. Similarly, the value of a customer is a reflection of both current and future profits. To find out how much economic value a customer creates for a company, the future cash flows from that customer would have to be adjusted for the cost of capital. ${ }^{26}$ Figure 1 illustrates how future cash flows can be used to determine the value of a customer or segment.

\section{MEASURING RETURNS FROM THE CUSTOMER PORTFOLIO}

The first step in measuring returns from the customer portfolio is to estimate the relationship lifetime. This is the period, in months or years, that the relationship with a customer is expected to last. Then the free cash flow (cash in minus cash out) has to be forecast. Applying a risk-adjusted discount rate to the free cash flows enables the net present economic value to be calculated.

\section{Cash in}

This is a function of current sales, sales growth rate, cash profit margin, direct and indirect costs. Direct costs are the direct product or service costs and will depend on the product mix that has been assumed in forecasting future sales to that segment. Sometimes, predictive modelling techniques are used by data managers to help marketing people 
forecast likely product mix. A key issue for data managers in measuring cash in arises where a company's IT systems are product based, perhaps because that is how the organisation is structured. Where there are a number of different systems within an organisation, each carrying part of the information about a customer, getting an overall picture of that customer's relationship with the organisation can be troublesome.

Sometimes, companies cannot even be clear about the number of products that a customer holds, because the information is not held centrally. Even where software is used to combine systems, data need to be cleaned and deduplicated so that marketing managers can be clear that 'Mr Jones' is the same as 'Mr E Jones' and 'E Jones'. Otherwise, poor $\mathrm{Mr}$ Jones gets three copies of each marketing mailshot. This is presumably irritating for $\mathrm{Mr}$ Jones and it is certainly inefficient for the company.

The relationship lifetime is another important variable that needs to be forecast before the true value of the customer relationship can be measured; increasingly, data mining tools are employed both to assess the likelihood of retention of certain customers and to identify behaviour patterns that warn of imminent defection. Such tools give marketing managers the opportunity to intervene and put a problem right before the customer relationship is lost, perhaps for ever. Another problem area is where customers have a relationship with a company, leave, and then return. Identifying continuity of relationship can be extremely difficult. Some data managers are employing sophisticated tools such as fuzzy logic to deal with this problem.

The biggest elements of indirect cost, often sales and general administration, ${ }^{27}$ should be specifically identified. This is usually done on an activity costing basis.
Activity-based costing can be an expensive exercise; fortunately, there are CRM tools that help companies to collect, analyse and understand the costs of doing business with their customers. For example, amount of sales time can be estimated, costed and shown against the specific segment, perhaps using time monitoring software. Call-centre systems may also automatically identify time spent, customer by customer. Other cost elements can be allocated on a pro rata basis.

\section{Cash out}

Cash out has three aspects: cash tax rate, fixed assets and working capital. The cash tax rate is likely to be the same for all customer segments and can therefore be disregarded in the analysis unless specific circumstances alter the actual tax rate.

To understand the total capital used to serve a segment, however, the fixed assets and working capital that are specific to that segment (or key account) have to be identified. Such assets might include plant and machinery; dedicated office space; customer-specific stock, services or paperwork. This is a major area where costs can differ between different customers or segments, yet managers may fail to take these costs into account when measuring the returns from the customer. Even apparently small matters such as customer-specific packaging can mean that extra resources may have to be dedicated to the customer, the special packaging might lead to higher wastage rates, the need for specialised warehousing and transport and so on. Tracking customer-specific costs is a problem for data managers where expenditures are allocated to a business area rather than to specific customers (this often happens when the costs are not being recharged to the customer). 


\section{WACC AND CUSTOMER RISK}

Since shareholder value is only created where the return on investment exceeds the weighted average cost of capital (WACC) the forecast free cash flows now have to be adjusted by the WACC. WACC is the true cost of capital of the business. It is calculated as the cost of debt multiplied by the proportion of debt funding, plus the cost of equity multiplied by the proportion of equity funding. The cost of debt is the company's current after-tax borrowing rate; the cost of equity is usually calculated as the amount by which the return on equities exceeds the return on long-dated government securities. This represents the additional compensation that stock market investors demand for investing their money in risky companies rather than in safe gilts. The WACC is the real cost to companies of borrowing money from the financial markets; if it then invests that money in developing customer relationships, the returns from those customers must be greater than the cost of capital if shareholder value is to be created.

When calculating the value of a relationship with a specific customer segment, many organisations apply a corporate discount rate to future cash flows to determine their net present value. Using the actual cost of capital (the WACC) to discount future cash flows from each segment will, however, give a truer picture of the total value of the customer portfolio than using a notional discount rate.

The analogy between the customer portfolio and the share portfolio can be extended still further. Some shares such as those in technology or biotechnology companies - are more risky than others. In the same way, some customers are more risky than others. Risk is defined as unanticipated volatility in returns ${ }^{28}$ so the riskiness of a segment could include the risks of sudden swings in buying patterns or amounts, defection (loss to a competitor) or even default.

This could lead a company to overvalue certain customer segments and perhaps to invest disproportionate time and resources in them while other, less capital intensive or less risky segments are neglected. All other things being equal, if two segments have the same level of expected future returns but one is more risky, the riskier segment will be less valuable to the company. Therefore, a discount rate higher than the WACC should be used to reflect the higher risk attributable to that customer segment. How much higher the discount rate should be will depend on how risky that segment is. So, managers need to be able to assess the risk of a customer.

\section{ASSESSING THE RISK OF A CUSTOMER OR SEGMENT}

Many companies assess the risk of their customers using some form of risk scorecard. This might be risk scoring by a risk assessment agency or may be carried out in-house. It is a standard procedure in retail financial services when customers apply for a mortgage, loan or credit card; and in the sale of consumer durables such as furniture, household appliances or cars where credit is to be given. Risk scoring is an effective way of evaluating certain specific types of customer risk, normally the risk of default.

Other types of risk associated with a customer, such as the risk of defection or purchasing swings, may not, however, be captured by traditional risk scoring. When a customer takes out a mortgage or personal loan, for example, the bank may have to arrange matching funding. If the customer then repays early, perhaps 
in order to switch to a competing lender, the bank is left with funds for which it has to find other borrowers. Similarly, a retailer attracting customers whose purchasing patterns are more volatile, runs more risk of stockouts and of excess stock than a retailer focusing on a segment that purchases similar amounts but in a predictable pattern. For existing customers, this volatility can be measured through analysis of previous purchase behaviour. These data can then be fed into the forecasts made by marketing managers for that customer, or for new customers of that type.

It follows from this that another way to assess the risk of a customer or segment is to look at the range of cash flow forecasts. The wider the dispersion (standard deviation) of the forecasts, the greater the risk. ${ }^{29}$ This methods works where a range of forecasts is available. In practice this may not be the case; managers often use point forecasts (one specific figure) rather than range forecasts, because this is simpler and quicker to do. IT-based management decision support tools such as forecasting or planning software may help encourage managers to make range forecasts; the data can then automatically be used to calculate expected volatility.

\section{Why is this customer riskier than that one?}

For marketing purposes and for the development of customer management strategies, it may be valuable to use a method for assessing customer risk that forces managers to define and evaluate customer risk for themselves. ${ }^{30}$ This can be done using a version of Repertory Grid technique ${ }^{31}$ that assigns weighted risk scores to each customer segment or to each key account.

The use of the weighted scoring approach is intended to ensure that all customers or segments are evaluated on a common basis. Using this process, managers' risk judgments about the risk of customers are relative to other parts of the customer portfolio. Various data might be needed to support the identification of relative risk, such as tendency to defect (customer lifetime), payment history, bad debt rates, purchasing volatility and so on.

One process for evaluating the risk of a customer has three steps:

- a list of the customer segments or key customers is made and a separate card is made for each named segment. Three cards at a time are randomly presented to each manager, who is asked to say which of the three names is most risky, and why. This process generates a set of risk factors. If the company already has some form of customer risk evaluation, such as credit scoring, the factors used for this can be taken into account

- the risk factors are then weighted by the managers according to perceived importance. It may become clear at this point that certain risk factors can be disregarded because their importance weighting is so low that they will have negligible impact on the final evaluation of customer risk - the managers then use this list of risk factors to evaluate the relative riskiness of each customer segment (or key account) being studied. The score for each risk factor is then multiplied by the importance weight for that factor and the individual weighted scores added to give a weighted risk assessment for each customer segment.

The marketing managers then use the weighted scores to make a judgment about the 'risk loading' that each segment (or key account) should bear. 
The baseline will be the WACC. The discount rate used for other customers or segments will then be the WACC adjusted for the risk associated with that customer or segment. For example, if one customer has a weighted score of 6.00 and another has a weighted score of 9.00 , the second customer could be assigned a risk loading that is 50 per cent higher than that of the first customer. Therefore, if the company's WACC is 10 per cent and managers estimate that the customer with a weighted risk score of 6.0 is the benchmark, the discount rate applied to the free cash flows from that customer should be the WACC, ie 10 per cent, and the discount rate for the second customer which has a risk rating of 9.0 should be 15 per cent $(10 \% \times 9.0 / 6.0)$.

\section{HOW WELL DOES PORTFOLIO THEORY FIT THE CUSTOMER PORTFOLIO?}

The use of the risk-weighting technique can be viewed as a departure from classic portfolio theory in which the specific risk of the individual asset is diversified away. The justification for this approach is that the analogy between the customer portfolio and the market portfolio is imperfect. For example, the weighting and therefore the impact of a major segment may be substantial; moreover, diversification may not reduce risk in the customer portfolio since the covariance of returns from certain segments might be positive, not negative. This might come about when two different segments are in fact related, such as certain mobile phone account customers and a younger, pay-as-you-go segment. If the former segment contains a high proportion of parents of the pay-as-you-go segment, switching behaviours in both segments might co-vary.

\section{DEVELOPING RISK AWARE CRM STRATEGIES}

From a customer relationship management perspective, analysing the risk of a customer or segment assists account managers to develop strategies to minimise the impact that risky segments might have on the supplier. For example, risk evaluations allow the marketing manager to make pricing decisions based on risk as well as return. The weighting and scoring approach has the merit of making it clear what the drivers of risk are; this is easier for marketing managers to turn into actionable customer management strategies such as differential pricing; or such risk reduction strategies as credit limits, cash deposits, insurance or guarantors.

Using a manager-defined concept of risk allows for a deeper study of the expected risk-return relationship. ${ }^{32} \mathrm{~A}$ wider definition of risk can be developed, enabling account managers to view the expected risk and return of the entire customer relationship. This in turn may suggest new customer relationship management strategies.

Figure 2 shows a segment that destroys value for the supplying company. This segment lies below the required return line, indicating that the returns from the segment do not compensate the supplier for the risks involved. Two sets of strategies for marketing managers are indicated, either of which will move these customers into the value-creating area above the line. The vertical arrow indicates conventional strategies to increase returns, such as cross-selling to increase revenue or switching the customer to Internet purchasing to reduce costs. There is, however, another set of strategies indicated by the horizontal arrow, which managers could use to reduce the risk of the segment. If risk is reduced sufficiently, as Figure 2 shows, the 


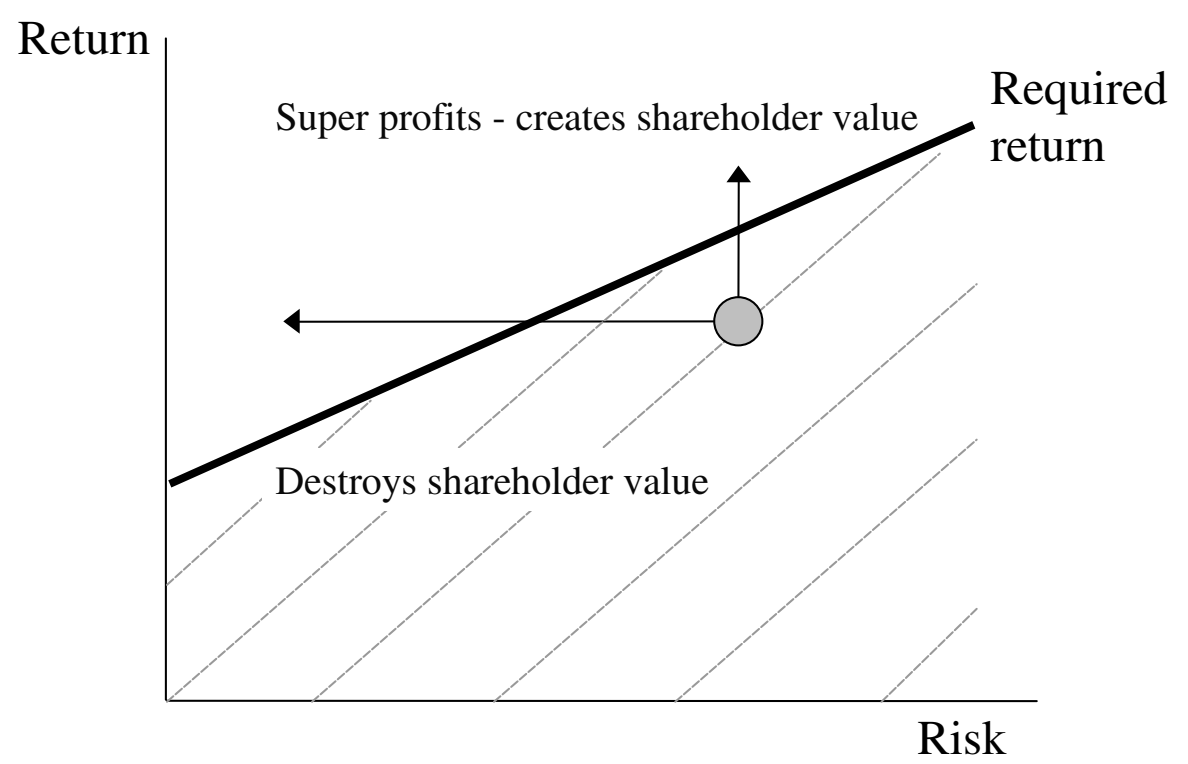

Figure 2: Paths to value creation

segment will create value for the organisation even if returns (revenues less costs) do not change. Risk-reducing strategies might include retention programmes to reduce the risk of purchasing volatility or customer information gathering to identify potential defectors. Some financial services organisations, for example, have analysed the pattern of customer defections and found that certain behaviours indicate potential defection. Customers whose transactional behaviours begin to show this pattern (which includes late payments, paying off a smaller proportion of the balance outstanding, and so on) can be contacted before they defect to find out if there is a problem with the relationship.

The two arrows in Figure 2 indicate two extremes; the vertical arrow indicates strategies purely aimed at increasing returns from a customer and the horizontal arrow indicates strategies designed purely to reduce risk. In practice, marketing managers may choose intermediate paths to value creation that combine strategies to increase returns with strategies to reduce risk. Thinking in terms of the customer portfolio alerts managers to both types of strategy.

\section{How risk aware managers can create more value}

At the overall business level, the managerial implications of applying portfolio theory to the customer portfolio are extremely interesting. In the first place, the process encourages a recognition that some customers are more valuable than others. In turn this can help organisations to understand that there are certain customers that can never create value for that organisation - in other words, customers that the firm would be better off without, or better off not attracting in the first place. This can help make relationship marketing activities more targeted towards value-creating customers.

Managing the customer base as a portfolio may also encourage the development of a broader range of strategies for customer relationship management. Marketing managers will 
still be interested in strategies to increase customer returns, such as increasing revenues by cross-selling or up-selling or reducing costs by migrating customers to less costly channels or encouraging them to use the organisation's services at times of lower demand. In addition, portfolio management techniques recognise that risk reduction strategies are as valid a route to value creation as strategies that are designed to increase returns.

\section{References}

1 Reichheld, F. F. (1993) 'Loyalty-based management', Harvard Business Review, Mar-Apr, pp. 64-73.

2 Christopher, M., Payne, A. and Ballantyne, D. (1991) 'Relationship marketing', Butterworth Heinemann, Oxford.

3 Blattberg, R. C. and Deighton, J. (1996) 'Managing marketing by the customer equity criterion', Harvard Business Review, July-August, pp. 136-144.

4 Reichheld, F. F. (1996) 'The loyalty effect', Harvard Business School Press, Harvard.

5 Hunt, S. D. (1997) 'Competing through relationships: Grounding relationship marketing in resource-advantage theory', Journal of Marketing Management, Vol. 13, No. 5, pp. 431-445.

6 Kutner, S. and Cripps J. (1997) 'Managing the customer portfolio of healthcare enterprises', The Healthcare Forum Journal, Vol. 40, No. 5, pp. $52-54$.

7 Grant, A. W. H. and Schlesinger, L. A. (1995) 'Realise your customers' full profit potential', Harvard Business Review, Vol. 75, No. 5, pp. 59-72.

8 Axson, D. A. J. (1992) 'A return to managing customer relationships', International Journal of Bank Marketing, Vol. 10, No. 1, pp. 30-35.

9 Webster Jnr, F. E. (1992) 'The changing role of marketing in the corporation', Journal of Marketing, Vol. 56, No. 4, pp. 1-16.

10 Srivastava, R. K., Shervani, T. A. and Fahey, L. (1999) 'Marketing, business processes and shareholder value: An organizationally embedded view of marketing activities and the discipline of marketing', Journal of Marketing, Vol. 63, Special Issue, pp. 168-179.

11 Day, G. and Fahey, L. (1998) 'Valuing marketing strategies', Journal of Marketing, Vol. 52, July pp. $45-57$.
12 Brealey, R. (1983) 'Risk and return on common stocks', MIT Press, Cambridge, MA.

13 Black, A., Wright, P. and Bachman, J. E. (1998) 'In search of shareholder value', Price Waterhouse, London.

14 Mills, R. and Turner, R. (1994) 'Projects for shareholder value', Henley Working Paper, 9426.

15 McNulty, J. (1997) 'Capital structures for shareholder value', conference presentation at 'Delivering shareholder value', Marakon Associates and HSBC James Capel, London.

16 Jagannathan, R. and McGrattan, E. (1995) 'The CAPM debate', Federal Reserve Bank of Minneapolis Quarterly Review, Vol. 19, No. 4, pp. 2-17.

17 Grinold, R. C. (1998) 'Is beta dead again?', http://www.barra.com/ResearchResources/ BarraPub/ibda-n.asp.

18 McNulty (1997) op. cit.

19 Leusner, J., Akhavein, J. D. and Swamy, P. A. V. B. (1996) 'Solving an empirical puzzle in the capital asset pricing model', Federal Reserve Board, pp. 1-33.

20 Lieber, R. B. (1996) 'Who are the real wealth creators?', Fortune, Dec, pp. 61-66.

21 Koller, T. (1994) 'What is value-based management?', McKinsey Quarterly, Vol. 3, pp. 87-101.

22 Thompson, D. A. R. (1997) 'How we have changed', conference presentation at 'Delivering shareholder value', Marakon Associates and HSBC James Capel, London.

23 Mariotti, J. (1996) 'Beyond activity-based costing: Try customer-based profitability accounting', Industry Week, Vol. 245, No. 22, p. 29, 2nd December.

24 Uyemara, D. G. (1997) 'EVA: A top-down approach to risk management', The Journal of Lending \& Credit Risk Management, Vol. 79, No. 6, pp. $40-47$.

25 Mariotti (1996) op. cit.

26 Black (1998) op. cit.

27 Howell, R. A. and Soucy, S. R. (1990) 'Customer profitability: As critical as product profitability', Management Accounting, Vol. 72, No. 4, pp. 43-47.

28 Copeland, T. E. and Weston, J. F. (1988) 'Financial theory and corporate policy', Reading, Mass.

29 Copeland and Weston (1988) Ibid.

30 McNamara, G. and Bromiley, P. (1999) 'Risk and return in organizational decision-making', Academy of Management Journal, Vol. 42, No. 3, pp. 330-339.

31 Harris, E. (1999) 'Project risk assessment: A European field study', British Accounting Review, Vol. 31, No. 3, pp. 347-371.

32 McNamara and Bromiley (1999) op. cit. 